\title{
Effects of Biochar and Biochar-Compost Mix on Growth, Performance and Physiological Responses of Potted Alpinia zerumbet
}

\author{
Faisal Zulfiqar ${ }^{1, *}{ }^{\oplus}$, Xiangying Wei ${ }^{2, *}$, Narmeen Shaukat ${ }^{3}$, Jianjun Chen ${ }^{4} \oplus$, Ali Raza ${ }^{5} \oplus$, Adnan Younis ${ }^{3, *}$, \\ Muhammad Nafees ${ }^{1}{ }^{(1)}$, Zainul Abideen ${ }^{6}{ }^{(0)}$, Abbu Zaid ${ }^{7}{ }^{\circledR}$, Nadeem Latif ${ }^{1}$, Muhammad Naveed ${ }^{8}$ \\ and Kadambot H. M. Siddique ${ }^{9}$ (I)
}

1 Department of Horticultural Sciences, Faculty of Agriculture and Environment, The Islamia University of Bahawalpur, Bahawalpur 63100, Pakistan; muhammad.nafees@iub.edu.pk (M.N.); nadeemmughal4480@yahoo.com (N.L.)

2 Institute of Oceanography, College of Geography and Oceanography, Minjiang University, Fuzhou 350108, China

3 Institute of Horticultural Sciences, University of Agriculture Faisalabad, Faisalabad 38040, Pakistan; narmeens99@gmail.com

4 Mid-Florida Research and Education Center, Environmental Horticulture Department, Institute of Food and Agricultural Sciences, University of Florida, 2725 South Binion Road, Apopka, FL 32703, USA; jjchen@ufl.edu

5 Fujian Provincial Key Laboratory of Crop Molecular and Cell Biology, Oil Crops Research Institute, Center of Legume Crop Genetics and Systems Biology/College of Agriculture, Fujian Agriculture and Forestry University, Fuzhou 350002, China; alirazamughal143@gmail.com

check for updates

Citation: Zulfiqar, F.; Wei, X.; Shaukat, N.; Chen, J.; Raza, A.; Younis, A.; Nafees, M.; Abideen, Z.; Zaid, A.; Latif, N.; et al. Effects of Biochar and Biochar-Compost Mix on Growth, Performance and Physiological Responses of Potted Alpinia zerumbet. Sustainability 2021, 13, 11226. https://doi.org/10.3390/ su132011226

Academic Editors: Gabriel Gascó Guerrero, Ana Méndez and Jorge Paz-Ferreiro

Received: 25 August 2021 Accepted: 5 October 2021 Published: 12 October 2021

Publisher's Note: MDPI stays neutral with regard to jurisdictional claims in published maps and institutional affiliations.

Copyright: (c) 2021 by the authors. Licensee MDPI, Basel, Switzerland. This article is an open access article distributed under the terms and conditions of the Creative Commons Attribution (CC BY) license (https:// creativecommons.org/licenses/by/ $4.0 /)$.
6 Muhammad Ajmal Khan Institute of Sustainable Halophyte Utilization, University of Karachi, Karachi 75270, Pakistan; zuabideen@uok.edu.pk

7 Plant Physiology and Biochemistry Section, Department of Botany, Aligarh Muslim University, Aligarh 202002, India; zaidabbu19@gmail.com

8 Institute of Soil and Environmental Sciences, University of Agriculture Faisalabad, Faisalabad 38040, Pakistan; mnaveeduaf@gmail.com

9 The UWA Institute of Agriculture, The University of Western Australia, Perth, WA 6001, Australia; kadambot.siddique@uwa.edu.au

* Correspondence: ch.faisal.zulfiqar@gmail.com (F.Z.); xiangyingwei@mju.edu.cn (X.W.); adnanyounis@uaf.edu.pk (A.Y.)

Abstract: Container crop production has become increasingly popular over the last 50 years. A major component of container or potting media is peat. Peatlands are a natural carbon sink, and peat is a nonrenewable natural resource. Peat harvesting has become an important environmental issue. There is a growing effort to explore alternative organic materials to completely or partially replace peat as a medium component. Biochar is a carbon-rich product that has gained increasing interest as a component of growing media. In the present study, biochar was produced from rice straw. Peat/perlite/biochar (PPB; 40/30/30 v/v) and peat/perlite/biochar/vermicompost (PPBC; 30/30/35/5 v/v) were evaluated relative to a basal or control medium of peat/perlite (PP; 70:30 v/v). Alpinia (Alpinia zerumbet 'Variegata Dwarf') was used as a test plant. Amending biochar and biocharcompost mix increased the $\mathrm{pH}$ of the growing media. Hydrophysical properties including container capacity, bulk density, air space and total porosity were all within or near the standard ranges for soilless growing media. Chlorophyll a and b contents of $A$. zerumbet plants grown in PPB medium were reduced by more than $20 \%$ and $28 \%$, respectively, compared to those grown in PP or PPBC media. The net photosynthetic rate of PPB-grown plants was more than $28 \%$ lower than those grown in PP and PPBC media. As a result, shoot and root dry weights of plants produced in PPB medium were more than $42 \%$ and $22 \%$ less, respectively, than those grown in PP and PPBC media. Although visual quality of PPB-grown plants was lower, they still exhibited marketable quality, which was largely due to the fact that their side shoots, leaf numbers, leaf areas, leaf thickness, and shoot diameters were comparable to those produced in PP and PPBC media. The present study showed that in a peat/perlite basal medium, substitution of peat by biochar derived from rice straw at $30 \%$ affected the growth of $A$. zerumbet plants, mainly in dry matter accumulation, but the plants were still marketable. On the other hand, plants grown in the same basal medium with peat replaced by the biochar at $35 \%$ plus an amendment of compost at $5 \%$ were comparable to those grown in the control medium. As the value of ornamental plants depends on their aesthetic appearance, a potting medium 
comprised of peat/perlite/biochar/vermicompost at 30/30/35/5 by volume is recommended for the production of $A$. zerumbet plants. The substitution of peat at $35 \%$ suggests that peat use can be reduced in the formulation of potting media, thus contributing to the conservation of peatlands.

Keywords: Alpinia; foliage plants; growing media; ornamental plants; peat alternatives; potted plants; soilless media; substrates

\section{Introduction}

The production of potted ornamental plants is highly specialized, intensive horticulture [1], which heavily relies on nonrenewable resources to attain uniformity and quality standards [2]. Among the nonrenewable resources, the horticulture industry broadly relies on peat [3], using it worldwide as a fundamental component of growing media for ornamental plant production [4]. Peat is the preferred organic component due to its excellent physiochemical characteristics, including relatively high cation exchange capacity (CEC), water retention, aeration, and suitability for supporting plant growth in a limited volume container $[3,5]$. However, peat use is restricted or regulated in some parts of the world because peatlands are natural carbon sinks, and peat is a nonrenewable resource [3]. There are ecological concerns related to peat harvest/mining, including declining biodiversity and climate change issues [6].

In light of this situation, interest is increasing among researchers to find economical and sustainable peat alternatives in potted plant production. Biochar, a carbon-rich charcoal-like material, is gaining importance for use as a component in horticulture growing media [7-12]. Biochar is produced at an industrial scale as a pyrolysis byproduct during bioenergy production processes for bio-oil and syngas $[13,14]$. Most biochars generally have a low bulk density and high CEC [15], but the properties of biochar are variable, and the $\mathrm{pH}$ is relatively high [16]. In addition, its effects on plant growth vary depending on the percentage used, biochar feedstock, growing conditions, and other media amendments $[7,8,17]$. Fascella et al. [18] reported that amendment with conifer wood biochar $(25 \% v / v)$ in peat-based growing media affected growth, mineral content, water use efficiency, and ornamental plant quality of potted Rosa rugosa. Gu et al. [19] reported that $30 \%$ (by volume) biochar amendment could be used for Gomphrena production under greenhouse conditions. In another study, amendment of conifer wood biochar $(60 \%$ or $80 \%$ by volume) in peat-based growing media enhanced plant height and dry biomass of Euphorbia $\times$ lomi due to improved physiochemical characteristics of the growing media after biochar incorporation [20]. More recently, Guo et al. [21] reported that $80 \%$ biochar amendment had no negative impact on the growth of Easter lily (Lilium longiflorum Thunb.).

Synergism between biochar and compost in growing media is a recent trend in growing media research [8,9]. Adding compost into growing media can be beneficial for enhancing nutrients and nutrient retention capacity [22] and improving chemical characteristics [23,24]. In a previous study, we used low rates of biochar and compost, solely or combined, for the production of potted dracaena (Dracaena deremensis) [8]. The plants grown in peat and perlite-based growing media amended with biochar (10\%) or biochar-compost blend ( $10 \%$ each by volume) had comparable growth to those grown in the control media. Similarly, Alvarez et al. [22] reported that petunia (Petunia hybrida) and geranium (Pelargonium peltatum) plants grown in mixtures containing vermicompost $(10-30 \%)$ and biochar (8-12\%) improved growth and flowering compared to the control. Liu et al. [25] evaluated the growth of bell pepper (Capsicum annuum L.) grown with pinewood biochar $(70 \%, 80 \%, 90 \%$, and $100 \%)$ and manure compost or vermicompost $(10 \%, 20 \%$, and $30 \%)$ relative to a commercial substrate. The biochar with vermicompost mixture improved physicochemical properties compared to biochar with manure compost. Huang et al. [23] investigated different concentrations of hardwood biochar combined with $5 \%$ vermicompost or chicken manure for the production of tomato (Solanum lycopersicum) 
and basil (Ocimum basilicum). They reported that vermicompost or chicken manure (5\%) with $60-70 \%$ biochar were suitable replacements for peat.

Alpinia (Alpinia zerumbet 'Variegated Dwarf'), commonly known as shell ginger, is a hardy ornamental plant with tough, bold, and sensational-looking foliage. It is a tender herbaceous perennial plant of the family Zingeberaceae. The 'Variegata Dwarf' is a small, compact cultivar bred for its irregular boldly patterned yellow and white foliage stripes. Alpinia has been considered an important ornamental foliage plant [1].

In this study, we hypothesized that high-quality of $A$. zerumbet plants could be produced in potting media supplemented with biochar or a biochar and compost mix. To test the hypothesis, three potting media were formulated, and their physicochemical properties were analyzed. Plant growth and final quality were evaluated. It was anticipated that this study could provide growers and producers in the foliage industry with information on appropriate use of biochar to substitute for peat in the formulation of potting media for quality foliage plant production.

\section{Materials and Methods}

\subsection{Growing Media Components}

Four growing medium components were used: (i) Peat (ScottsMiracle-Gro ${ }^{\circledR}$, Marysville, $\mathrm{OH}, \mathrm{USA}$ ), (ii) perlite (ScottsMiracle-Gro ${ }^{\circledR}$ ), (iii) rice straw biochar as BC, and (iv) vermicompost (Magical Gro). Commercial peat and perlite were purchased from a local gardening company. The peat had a $\mathrm{pH}$ ranging from 4.5 to 5.5 , and concentrations of $\mathrm{N}, \mathrm{P}$, and $\mathrm{K}$ were $1 \%, 0.04 \%$, and $0.1 \%$, respectively. $\mathrm{BC}$ was produced from the pyrolysis of rice straw at $350^{\circ} \mathrm{C}$ using a muffle furnace (LH 120/12; Nabertherm GmbH, Bahnhofstr, Germany) with $2 \mathrm{~h}$ residence time. The $\mathrm{BC}$ had a pH of 7.6, contents of $\mathrm{N}, \mathrm{P}$, and $\mathrm{K}$ at 10.27, 1.39, and $10.31 \mathrm{~g} \mathrm{Kg}^{-1}$, respectively. The choice of this temperature was based on the notion that mineral elements such as $\mathrm{P}, \mathrm{K}, \mathrm{Ca}, \mathrm{Mg}, \mathrm{Fe}, \mathrm{Cu}, \mathrm{Zn}$, and $\mathrm{Si}$ would increase with pyrolysis temperature, while their bioavailability would decrease [26], To ensure more bioavailable nutrients, a low temperature was used in this study. There was a possibility that a minimum content of $\mathrm{O}_{2}$ might occur in the furnace, but it was likely below $2 \%$. Vermicompost (Black diamond vermicompost) was purchased from a local gardening company. The vermicompost had a $\mathrm{pH}$ of 6.0 , contents of $\mathrm{N}, \mathrm{P}$, and $\mathrm{K}$ at $1.5 \%, 1.0 \%$, and $0.5 \%$, respectively.

\subsection{Preparation of Growing Media}

Three growing media were formulated using the abovementioned components: (i) peat:perlite at 70:30 by volume, designated as PP. Foliage plants are commonly produced in commercial potting media containing $50 \%$ to $70 \%$ of peat by volume [1], including the University of Florida Foliage Plants Mix 3 consisting of $75 \%$ peat and $25 \%$ sand, Vergo Container Mix A composed of $60 \%$ peat, $20 \%$ vermiculite, and $20 \%$ perlite [27] as well as a medium with $70 \%$ peat and $30 \%$ perlite used for the production of the foliage plant Syngonium [9]. Thus, the PP was considered as a common and control medium in this study. (ii) Peat:perlite:BC at 40:30:30 based on volume, designated PPB. (iii) Peat:perlite:BC:vermicompost at 30:30:35:5 by volume, designated PPBC. In our previous studies, peat was replaced by $10 \%$ of a biochar for producing Dracaena [ 8 ] and by $20 \%$ of a biochar for producing Syngonium [9]. This study was intended to test $30 \%$ substitution.

\subsection{Physicochemical Characteristics of Growing Media}

The physical properties of the three media or substrates were analyzed using the methods described by Tian et al. [28], Méndez et al. [29], and Neito et al. [30]. Accordingly, a known volume container (3 litre: $15 \mathrm{~cm}$ height, $19 \mathrm{~cm}$ top diameter, $13 \mathrm{~cm}$ base diameter) with a tightly sealed drainage hole at the bottom was filled with a growing substrate and then slowly saturated by gradually pouring water on the surface of the container. Next, the filled container was held over a watertight pan, and the bottom seal was removed from the drain hole to drain freely for at least $10 \mathrm{~min}$. By recording the volume of drained water, air space was determined. Afterward, the saturated substrate was weighed, kept 
in an aluminum pan, and allowed to dry for $24 \mathrm{~h}$ at $105^{\circ} \mathrm{C}$. By recording the dry mass of the substrate, we measured the amount of water that was dried off the substrate to obtain the volume of water held by the substrate (water-holding capacity). Total porosity was determined as the addition of the air space and the water-holding capacity [28]. All experiments were performed in triplicate.

The $\mathrm{pH}$ and electrical conductivity (EC) of the formulated substrates were determined using a ratio sample: water 1:10 (weight: volume) with an $\mathrm{AB} 15 \mathrm{pH}$ meter (Thermo Fisher Scientific, Waltham, MA, USA) and a digital EC meter (Lovibond Senso Direct 150), respectively [31,32] All tests were performed in triplicate.

\subsection{Plant Growth Experiment}

A greenhouse experiment was conducted at the Floriculture Research Facility, the University of Agriculture Faisalabad, Pakistan, from mid-May 2017 to mid-October 2017. Inside the greenhouse, the daily air temperature was maintained below $28{ }^{\circ} \mathrm{C}$, while the night temperature was above $14{ }^{\circ} \mathrm{C}$. Two-month-old Alpinia seedlings derived from cultured tissue liners in plug trays, imported from China, were purchased from a local nursery (Best Garden Nursery, Faisalabad, Pakistan). Seedlings were transplanted into $4 \mathrm{~L}$ containers ( $21 \mathrm{~cm}$ diameter top, $15.5 \mathrm{~cm}$ diameter base, and $17 \mathrm{~cm}$ depth) filled with the three growing media on 16 May 2017. The experiment was arranged as a completely randomized design with 12 replications.

\subsection{Photosynthetic Pigments and Leaf Gas Exchange}

Three days before harvest, leaf greenness of fully extended leaves on each plant was measured using a portable SPAD 502 (Konica Minolta, Osaka, Japan) on three leaves per plant, one each from the top, middle and bottom, and averaged. Leaf gas exchange was measured on the same day. A portable infrared $\mathrm{CO}_{2} / \mathrm{H}_{2} \mathrm{O}$ gas exchange system LI-COR 6400 (LI-COR, Lincoln, NE, USA), set at $400 \mu \mathrm{mol} \mathrm{m}{ }^{-2} \mathrm{~s}^{-1} \mathrm{CO}_{2}$ and $300 \mu \mathrm{mol} \mathrm{m}^{-2} \mathrm{~s}^{-1}$ flow rate, was used to perform onsite measurements on three mature, healthy, and fully emerged leaf blades from each of the six plants per treatment between 9.00 and $11.00 \mathrm{am}$. This method provided precise net photosynthetic or carbon assimilation rate $\left(P n, \mu \mathrm{mol} \mathrm{m}{ }^{-2} \mathrm{~s}^{-1}\right)$, transpiration rate $\left(E, \mathrm{mmol} \mathrm{m} \mathrm{m}^{-2} \mathrm{~s}^{-1}\right)$, and stomatal conductance $\left(g s, \mathrm{mmol} \mathrm{m}^{-2} \mathrm{~s}^{-1}\right)$. The fresh leaves used for the gas exchange measurements were cut from the plant, sealed in plastic bags, and transported to the laboratory in a cool box to measure chlorophyll contents. Chlorophyll a and b contents were determined following Arnon [33] using $500 \mathrm{mg}$ fresh leaf extracted overnight with $80 \%$ acetone and centrifuged at $10,000 \times g$ for $5 \mathrm{~min}$. Total chlorophyll and chl $\mathrm{a} / \mathrm{b}$ ratio was measured by adding and dividing chl $\mathrm{a}$ and $\mathrm{b}$ contents, respectively.

\subsection{Leaf Mineral Contents}

Leaf nitrogen content $(\mathrm{N})$ was determined using the Kjeldahl method according to Jackson [34]. Leaf phosphorus (P) and potassium (K) contents were determined according to Chapman and Pratt [35].

Nondestructive parameters, such as number of side shoots, leaf number per plant, leaf area, leaf thickness, and main shoot diameter were measured. Leaf area was measured using a LI-COR-3000C Portable Area Meter (LI-COR, Lincoln, NE, USA). Leaf thickness and main shoot diameter were measured using a digital Vernier caliper. At the termination of the trial (15 October; 150 days after transplanting DAT), eight plants per treatment were uprooted carefully and washed with tap water to remove adhered growing media. Afterward, plants were cut with a sharp cutter and separated into shoots and roots. The tissues were placed separately in an oven and allowed to dry at $70^{\circ} \mathrm{C}$ for $72 \mathrm{~h}$ until constant weight to determine dry weight. 


\subsection{Visual Quality Grading}

At the end of experiment, the overall appearance of plants was graded visually, where: 1 = non-marketable quality (i.e., decolorization, less brightness, necrotic tissues); 2 = medium quality (i.e., small size, decolorization, less brightness); $3=$ good quality / saleable (no decolorization, bright leaves, small size); $4=$ excellent/high quality (no decolorization, bright leaves, normal size).

\subsection{Statistical Analysis}

Data were analyzed statistically using Minitab ${ }^{\circledR} 19$ (Minitab, Inc., State College, PA, USA). A one-way analysis of variance (ANOVA) was applied to determine differences among treatments for all studied parameters. Treatments with biochar and biochar-compost mixture were compared to the control using Tukey's Honest Significant Difference (HSD) test (Tukey's HSD), and means were separated when treatments were significant at $p<0.05$. The principal component analysis (PCA) was performed using XLSTAT ver. 2019.2.2.59614 (Addinsoft Inc., New York, NY, USA).

\section{Results and Discussion}

\subsection{Physicohemical Properties of Growing Media}

The physical properties of growing media are important because they (i) have a strong impact on the availability of air and water to plant roots and (ii) cannot be changed by growers. Furthermore, the volume of growing media per plant is relatively small compared to field conditions, underlining the importance of physical properties [30]. Therefore, characteristics such as water-holding capacity, bulk density, total porosity, and air space of growing media affect containerized plant growth [36].

Table 1 shows the physical properties and $\mathrm{pH}$ of the formulated growing media. According to Chen et al. [37] and Abad et al. [38], the bulk density (BD) of an ideal organic substrate should be $<0.40 \mathrm{~g} \mathrm{~cm}^{-3}$, which was the case for all treatments in this study (Table 1). The BD of PP was $0.11 \mathrm{~g} \mathrm{~cm}^{-3}$. The addition of $\mathrm{BC}$ to the PP growing medium increased BD to $0.19 \mathrm{~g} \mathrm{~cm}^{-3}$, while the BD in PPBC increased to $0.17 \mathrm{~g} \mathrm{~cm}^{-3}$. Although not determined in this study, $\mathrm{BD}$ variation may be due to particle size variation of the substrate components [36] or the high BD of amended biochar [39]. Higher BD increases the weight and thus transportation and labor costs for ornamental potted plants [36]. Our results agree with those of Huang et al. [23], who showed that biochar and compost amendment increased BD of substrate mixtures. Blending different dry substrates will increase BD if the substrates fit with each other tightly [36]. Thus, using biochar with high BD to substitute peat could increase the BD of substrates [39].

Table 1. Main hydrophysical properties of growing media.

\begin{tabular}{cccccc}
\hline Medium & $\mathbf{p H}$ & Air Space (\%) & Bulk Density $\left(\mathbf{g ~ c m}^{-3}\right)$ & Total Porosity (\%) & Container Capacity (\%) \\
\hline PP & $5.75 \mathrm{~b}$ & $9.2 \mathrm{~b}$ & $0.11 \mathrm{~b}$ & $73.51 \mathrm{a}$ & $63.20 \mathrm{a}$ \\
PPB & $7.57 \mathrm{a}$ & $14.64 \mathrm{a}$ & $0.19 \mathrm{a}$ & $74.12 \mathrm{a}$ & $65.74 \mathrm{a}$ \\
PPBC & $7.68 \mathrm{a}$ & $14.18 \mathrm{a}$ & $0.17 \mathrm{a}$ & $68.66 \mathrm{~b}$ & $53.43 \mathrm{~b}$ \\
\hline
\end{tabular}

PP, PPB, and PPBC were peat:perlite (70:30 by volume), peat:perlite:biochar (40:30:30), and peat:perlite:biochar:vermicompost (30:30:35:5), respectively. Values in columns followed by the same letter do not significantly differ at the $p<0.05$ level based on the Tukey HSD test ( $\mathrm{n}=12$ ).

Total porosity (TP) is defined as the percent of pores in the growing media [40] and is the sum of water-holding capacity and air space [23]. The peat products on the market have different physical properties, ranging from a very low decomposed white peat to a more decomposed black sphagnum peat. Total porosity is an indicator of the stage of peat decomposition. The peat used in our experiment had 73.5\% lower TP than the white peat used by Gruda and Schnitzler [41], but higher TP than the peat-vermiculite mixture used by Xing et al. [42]. The PPB had a similar TP to PP, but the PBC had significantly lower TP than PP and PPB (Table 1). 
The percent of pores filled with air after water drainage is the air space. In this study, the air space of all treatments fell within the ideal range (10-30\%) for soilless container growing media $[41,43]$. PPB and PPBC had more air space $(14.64 \%$ and $14.18 \%)$ than PP (9.2\%) (Table 1.). These results agree with Huang et al. [23], Vaughn et al. [16], and Tian et al. [28], who reported enhanced air spaces in biochar-compost mixture or individual biochar applications. However, the physical properties of the different biochar and individual compost materials varied. Liu et al. [25] also reported enhanced air space in biochar and compost-based growing media compared to the commercial substrate used for pepper production. Zhang et al. [44] confirmed this by showing that mixing biochar with compost increased the percentage of particles larger than $2 \mathrm{~mm}$ and thus increased the air space. However, Méndez et al. [45] reported that biochar amendment in peat-based growing media had no significant effect on air space. These studies used biochars and composted materials of different origins, with different physiochemical properties [8].

The ideal range for container capacity or water-holding capacity for potting media is 45-65\% [41]; the three media fell within this range (Table 1). Our results showed that the incorporation of $30 \%$ of BC did not significantly increase water-holding capacity, which was different from the results reported by Méndez et al. [29], who reported that incorporating $50 \%$ biochar with $50 \%$ peat increased the water-holding capacity of growing media compared to those containing $100 \%$ peat. However, the addition of $5 \%$ compost in the PPBC medium significantly reduced water-holding capacity (Table 1). This concurred with the report of Huang et al. [23], where incorporating different percentages of biochar with $5 \%$ of two different composts decreased the water-holding capacity. The variable results could be due to variation in the physical properties of the growing media. The water-holding capacity of biochar can be affected by the biochar feedstock [46]. Gruda and Schnitzler [41] amended Toresa spezial (70\%) and Toresa nova (50\%) materials with 30\% and $50 \%$ white peat, respectively. The authors reported that white peat had the highest readily available water ( $35 \mathrm{vol} . \%)$ alone, while amendments of Toresa spezial and Toresa nova showed a range close to the ideal substrate. The authors demonstrated that the fine particle material had more readily available water than coarse material.

The PP had a slightly acidic $\mathrm{pH}$ of 5.75, whereas PPB and PPBC had slightly basic $\mathrm{pH}$ values of 7.57 and 7.68 , respectively, mainly due to the higher $\mathrm{pH}$ of the raw components, i.e., biochar and compost, amended in these two growing media. Our results agree with a previous study where the incorporation of biochar $(10 \%)$ or a mixture of biochar $(10 \%)$ and compost (10\%) into peat-perlite-based growing media increased $\mathrm{pH}$ values but did not affect the growth of an ornamental foliage plant Dracaena deremensis [8]. In another study, biochar $(50 \% v / v)$ with peat-based growing media at $\mathrm{pH} 7.11$ produced greater biomass of Calathea rotundifolia than pure peat (100\%) at $\mathrm{pH} 6.2$ [28]. Vaughn et al. [16] recommended using food-grade citric acid to tackle the high $\mathrm{pH}$ value associated with the addition of biochar in growing medium. Margenot et al. [47] reported that $\mathrm{pH}$ adjustment suitability using pyrogenic acid depends on plant growth stage. Margenot et al. [47] observed a negative effect of $\mathrm{pH}$ adjustment at seed germination, but no adverse effects of $\mathrm{pH}$ adjustment during later growth.

\subsection{Plant Physiological Parameters}

Chlorophyll a contents for plants grown in PP and PPBC were comparable at 2.18 and $2.52 \mathrm{mg} \mathrm{g}^{-1} \mathrm{FW}$, respectively; however, they significantly decreased $\left(1.75 \mathrm{mg} \mathrm{g}^{-1} \mathrm{FW}\right)$ for those grown in PPB (Figure 1). A similar trend occurred for Chl b and SPAD values. Total Chl contents, however, ranked $\mathrm{PPB}<\mathrm{PP}<\mathrm{PPBC}$. Similar results were demonstrated by Margenot et al. [47], in which the chlorophyll values (SPAD) decreased with the high substitution of biochar. While PPBC had a higher biochar rate than PPB, the addition of compost, which is generally rich in nutrient elements and organic acids, might act as a buffer to improve media properties. Chlorophyll contents are directly related to leaf $\mathrm{N}$ acquisition. At the same time, biochar has a binding effect on $\mathrm{N}$ [48]. The mechanisms underlying the biochar adsorption of $\mathrm{N}$ was due predominantly to ion exchanges [49]. A 
high rate of biochar substitution, like PPB, would result in increased adsorption of $\mathrm{N}$ in the biochar, which could explain the reduced $\mathrm{N}$ content in leaves and low chl contents. On the other hand, the leaf $\mathrm{N}$ content in plants grown in PPBC was 3.22\%, compared to $1.43 \%$ in PPB (Figure 2). Thus, chl contents were highest in PPBC, likely due to the availability of $\mathrm{N}$ in compost.

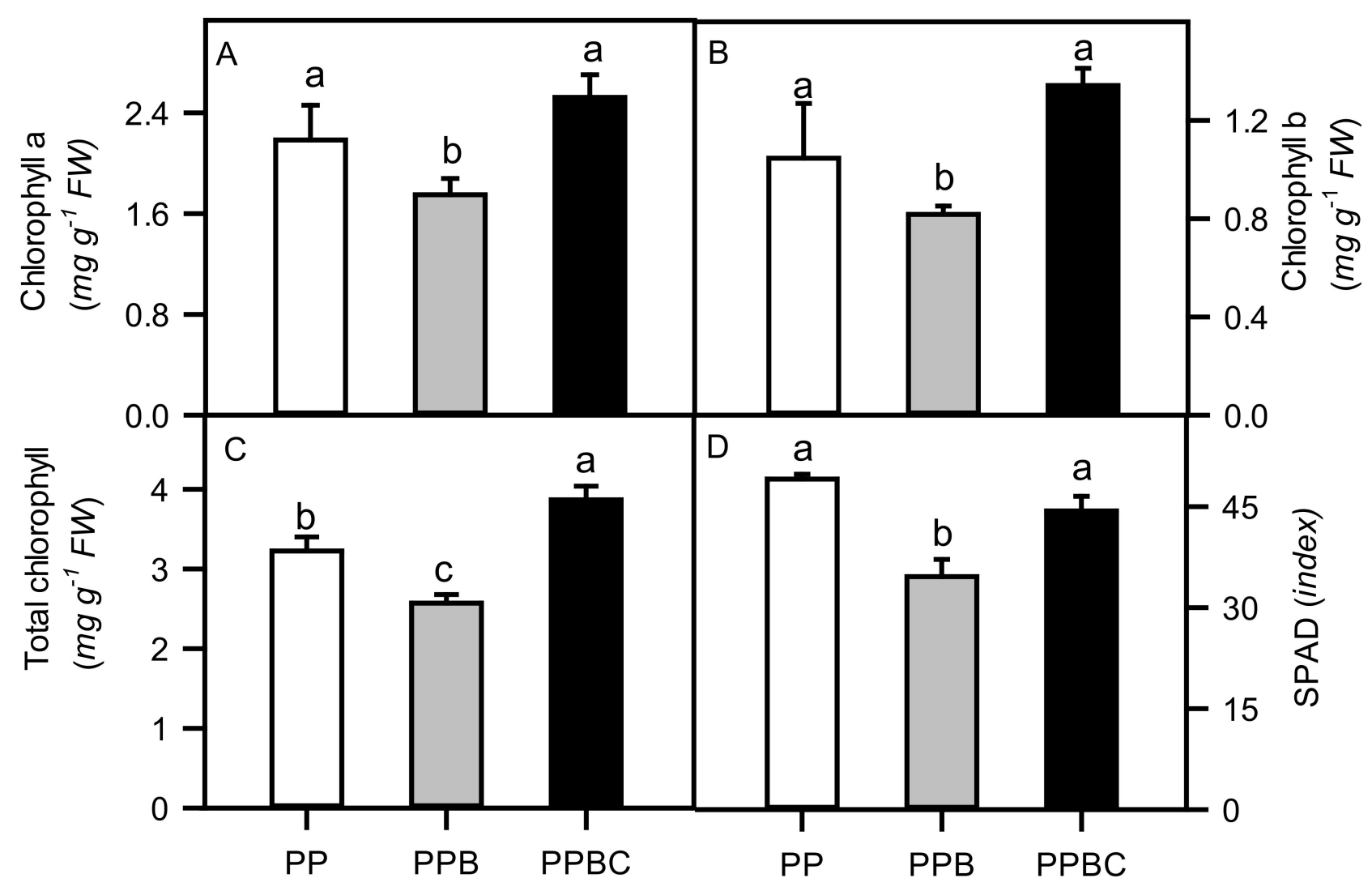

\section{Treatments}

Figure 1. Chlorophyll a (A), chlorophyll b (B), total chlorophyll (C) and SPAD readings (D) of Alpinia zerumbet plants grown in peat:perlite (PP), peat:perlite:biochar, and peat:perlite:biochar:compost (PPBC) media. Data are the mean $\pm S E(n=12)$. Different letters above the bars represent significant differences according to Tukey's HSD test at $p<0.05$ level.

The growing media treatments significantly affected leaf $\mathrm{N}$ content, with PPBC the highest (3.22\%) followed by PP (2.57\%), and PPB the lowest N (1.43\%) (Figure 2). There has been no report on the optimal $\mathrm{N}$ content in leaves of $A$. zerumbet. However, an optimal range of $\mathrm{N}$ in a relative of $A$. zerumbet, $A$. purpurata was documented to be $2.19-2.7 \%$ [50], suggesting that plants grown in PPB did not absorb needed $\mathrm{N}$ in this study. These findings agree with Tian et al. [28], where $\mathrm{N}$ decreased following 50\% replacement of peat with biochar, perhaps due to the $\mathrm{N}$ binding effect of biochar. The growing media treatments significantly affected leaf P content. Relative to PP (control) $(0.49 \%)$, leaf P contents were lower for PPB (0.15\%) and PPBC (0.31\%) (Figure 2). Low leaf P could be due to higher $\mathrm{pH}$ values of potting media reducing $\mathrm{P}$ availability and limiting the ability of roots to absorb $\mathrm{P}$. The growing media treatments also significantly affected leaf $\mathrm{K}$ content. Plants grown in PPB and PPBC had significantly lower leaf $K$ contents than the control (Figure 2). These results differ from Kim et al. [51], who reported an increase in N, P, and K contents with $1-5 \%$ rice straw biochar amendment, likely due to differences in the biochar and compost properties and $\mathrm{pH}$ of the growing media. 


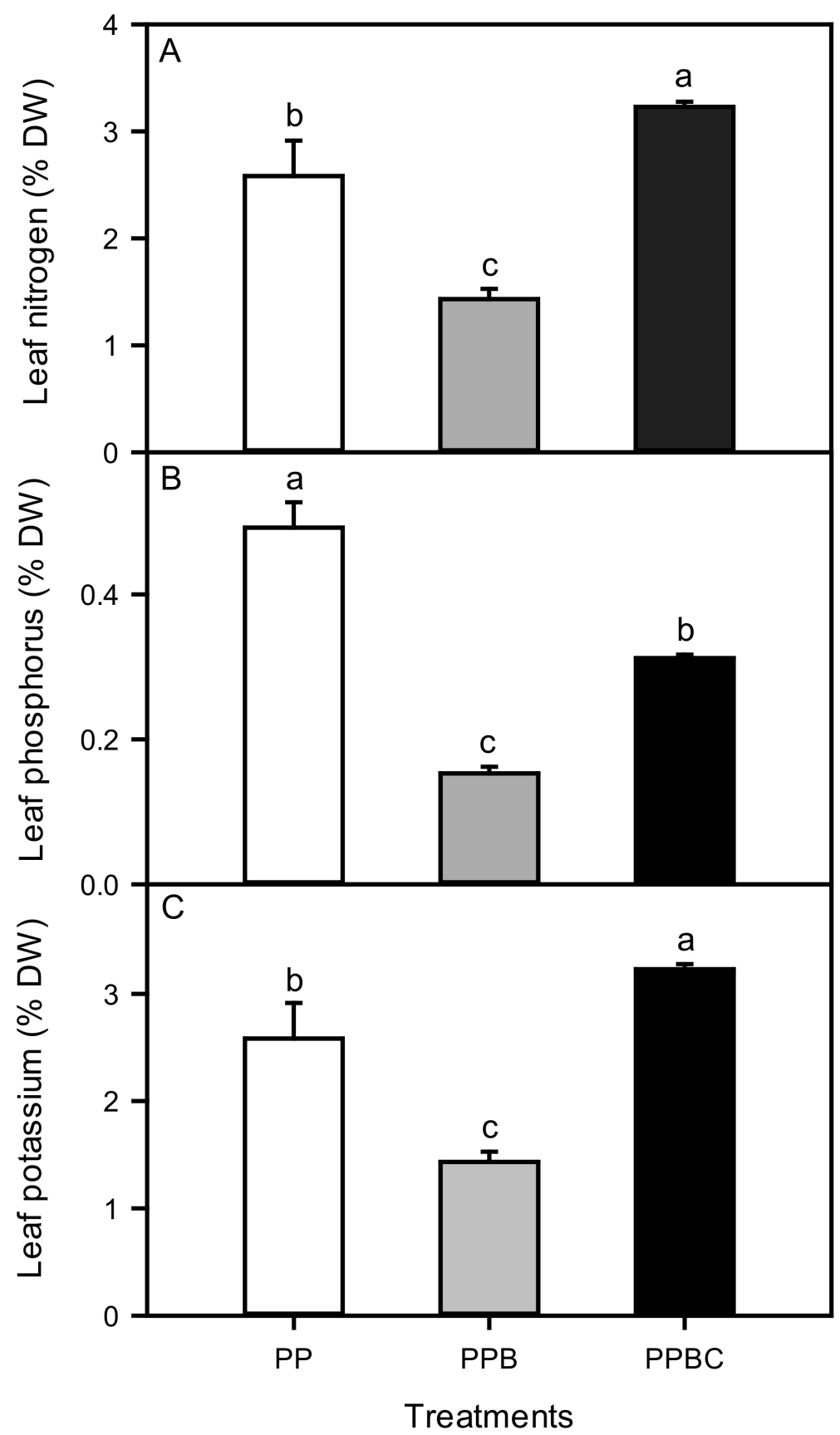

Figure 2. Leaf nitrogen (A), phosphorus (B) and potassium (C) contents of Alpinia zerumbet plants grown in peat:perlite (PP), peat:perlite:biochar, and peat:perlite:biochar:compost (PPBC) media. Data are the mean $\pm \mathrm{SE}(\mathrm{n}=12)$. Different letters above the bars represent significant differences according to Tukey's HSD test at $p<0.05$ level.

Similar to the $\mathrm{Chl}$ values, the net photosynthetic rate of plants grown in PPB was $5.64 \mu \mathrm{mol}\left(\mathrm{CO}_{2}\right) \mathrm{m}^{-2} \mathrm{~s}^{-1}$, which was significantly lower than those of plants grown in PP and PPBC media (Figure 3). However, the growing media treatments did not significantly affect leaf gas exchange traits, which could be due to the physical properties of the growing media. Furthermore, the feedstock of biochar and compost could have different effects on plant physiological traits. These results support a previous study's findings that biochar amendment did not affect these traits [52]. 


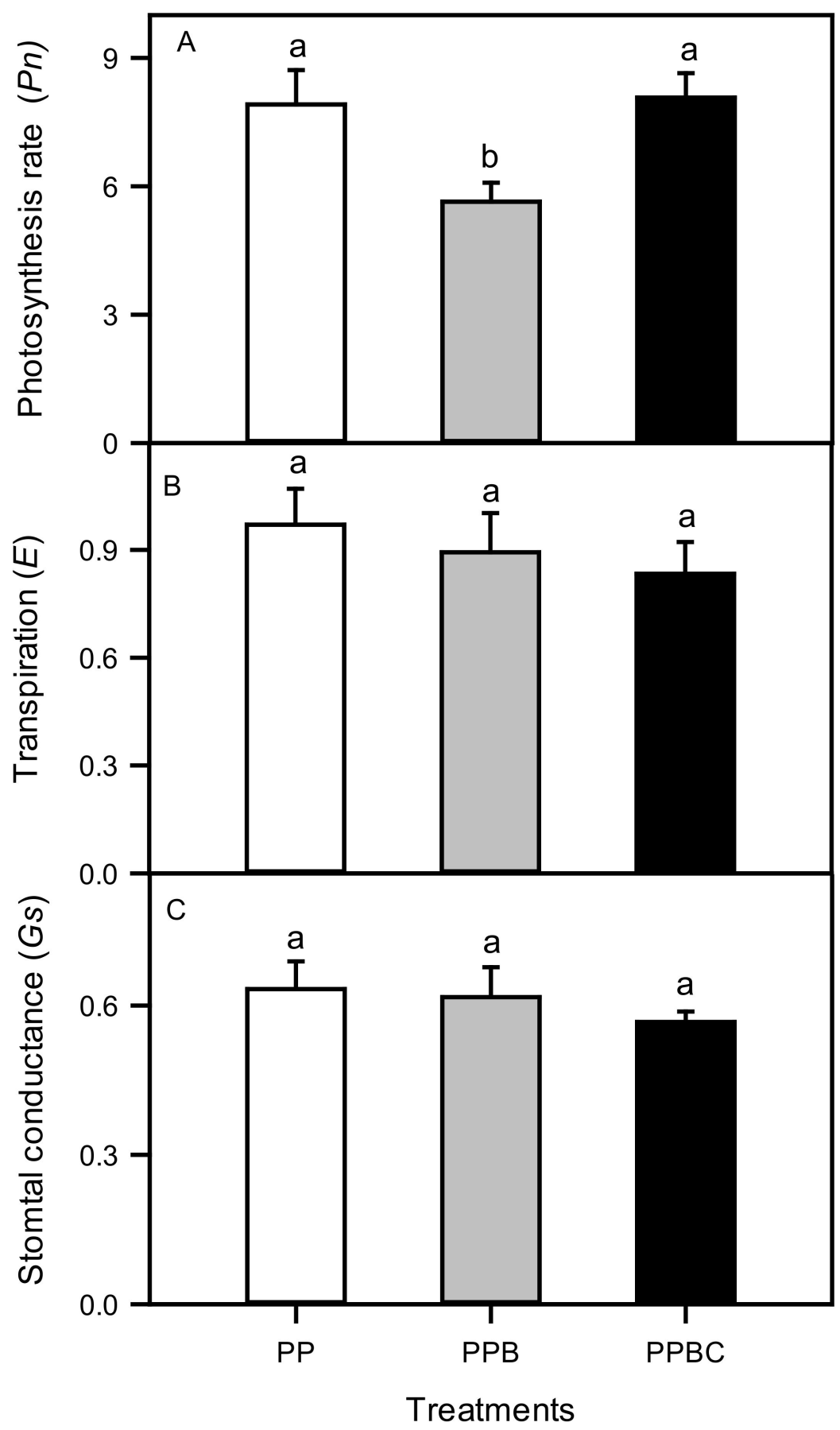

Figure 3. Photosynthesis rate $\left[\mu \mathrm{mol}\left(\mathrm{CO}_{2}\right) \mathrm{m}^{-2} \mathrm{~s}^{-1}\right.$; (A)], transpiration $\left[\mathrm{mmol}\left(\mathrm{H}_{2} \mathrm{O}\right) \mathrm{m}^{-2} \mathrm{~s}^{-1}(\mathbf{B})\right]$ and stomatal conductance $\left[\mathrm{mol}\left(\mathrm{H}_{2} \mathrm{O}\right) \mathrm{m}^{-2} \mathrm{~s}^{-1}(\mathbf{C})\right.$ of Alpinia zerumbet plants grown in peat:perlite (PP), peat:perlite:biochar, and peat:perlite:biochar:compost (PPBC) media. Data are the mean $\pm \mathrm{SE}$ $(\mathrm{n}=12)$. Different letters above the bars represent significant differences according to Tukey's HSD test at $p<0.05$ level.

\subsection{Growth of A. zerumbet in the Three Growing Media}

Replacing the basal medium (PP) with biochar (PPB) or biochar-compost mix (PPBC) maintained plant growth similar to PP, which concurred with the report of Zulfiqar et al. [8] that wheat straw biochar alone and combined with green waste compost sustained plant growth of the ornamental plant Dracaena deremensis compared to peat-perlite (70:30 v/v).

The number of side shoots and leaf number of A. zerumbet plants grown PPB medium were lower than those grown in PP and PPBC, however not significantly so (Table 2). 
Similarly, there were no significant differences in leaf areas, shoot diameters and leaf thickness among plants growth in the three media. However, dry matter accumulation varied significantly. Shoot dry mass was $2.00,1.01$, and $1.71 \mathrm{~g} \mathrm{plant}^{-1}$, respectively, for PP, PPB, and PPBC. The corresponding root dry masses were $8.56,6.68$, and $9.70 \mathrm{~g} \mathrm{plant}^{-1}$ (Table 2). The reduced dry matter accumulation in PPB-grown plants was closely related to the decrease in $\mathrm{Chl}$ contents and $P n$ rate (Figures 1 and 3), which in turn were attributed to a decline in mineral nutrient contents (Figure 2) due to the high rate of biochar amendments. These results differ from those of Kim et al. [49], who reported enhanced root and shoot dry biomass (192\% and 150\%) of kale (Brassica oleracea L. var. acephala) when rice hull biochar $5 \%(w / w)$ was added into coir dust, perlite, and vermiculite-based growing media. There could be numerous reasons for the different results, including variation in individual components, amendment rate, and plant species requirements $[17,53]$. Housley et al. [54] reported that the aboveground biomass of Viola $\times$ hybrid was unaffected by a $5 \%(w / w)$ amendment with Eucalyptus saligna wood chip biochar but decreased with a $10 \%(w / w)$ amendment, which is likely related to the concentrations of individual components (biochar and compost).

Table 2. Effect of growing media on number of side shoots, number of leaves, leaf area, shoot diameter, leaf thickness, shoot and root dry biomass weight, and visual quality of potted Alpinia zerumbet plants.

\begin{tabular}{|c|c|c|c|c|c|c|c|c|}
\hline Medium & $\begin{array}{c}\text { Number of } \\
\text { Side } \\
\text { Shoots }\end{array}$ & $\begin{array}{c}\text { Number of } \\
\text { Leaves per } \\
\text { Plant }\end{array}$ & $\begin{array}{l}\text { Leaf Area } \\
\quad\left(\mathrm{cm}^{2}\right)\end{array}$ & $\begin{array}{c}\text { Shoot } \\
\text { Diameter } \\
(\mathrm{mm})\end{array}$ & $\begin{array}{c}\text { Leaf } \\
\text { Thickness } \\
(\mathrm{mm})\end{array}$ & $\begin{array}{l}\text { Shoot Dry } \\
\text { Mass } \\
\text { (g) }\end{array}$ & $\begin{array}{l}\text { Root Dry } \\
\text { Mass } \\
\text { (g) }\end{array}$ & $\begin{array}{c}\text { Visual } \\
\text { Quality }\end{array}$ \\
\hline PP & $4.0 \mathrm{a}$ & $10.83 a$ & $36.68 a$ & $11.95 a$ & $0.17 \mathrm{a}$ & $2.00 \mathrm{a}$ & $8.56 a$ & $4.0 \mathrm{a}$ \\
\hline РPB & $3.5 a$ & $8.33 a$ & $29.83 a$ & $11.08 \mathrm{a}$ & $0.19 a$ & $1.01 \mathrm{~b}$ & $6.68 \mathrm{a}$ & $3.3 b$ \\
\hline РPBC & $4.3 \mathrm{a}$ & $9.16 a$ & $27.31 \mathrm{a}$ & $9.96 a$ & $0.19 a$ & $1.71 \mathrm{a}$ & $9.70 \mathrm{a}$ & $4.0 \mathrm{a}$ \\
\hline
\end{tabular}

PP, PPB, and PPBC were peat:perlite (70:30 by volume), peat:perlite:biochar (40:30:30), and peat:perlite:biochar:vermicompost (30:30:35:5), respectively. Values in columns followed by the same letter do not significantly differ at the $p<0.05$ level based on the Tukey HSD test ( $\mathrm{n}=12$ ).

\subsection{Visual Quality}

The visual quality of the Alpinia plants grown in PPB medium significantly decreased (3.3) compared to PP and PPBC (4.0) (Table 2). Decreased visual quality is likely linked to the lower leaf $\mathrm{N}$ concentration compared to control or to growing media characteristics, while enhanced visual quality might be associated with enhanced leaf $\mathrm{N}$ concentration. Visual quality is related to the appearance/ornamental marketability of plant vigorousness, overall look, and discoloration, symptoms, or marks. Usually, it is these criteria the customer considers when purchasing potted ornamentals, not plant biomass or size. In general, ornamental plants with a visual quality rating of $\geq 3.0$ are considered saleable in the marketplace [55]. However, high price is generally given to plants with higher quality. Thus, to produce highly marketable $A$. zerumbet plants, a medium comprised of peat/perlite/biochar/compost at a ratio of $30 / 30 / 35 / 5$ should be used.

\subsection{Principal Component Analysis}

To evaluate the effects of PP, PPB, and PPBC on the growth parameters of potted A. zerumbet plants, the score and loading plots of PCA were implemented (Figure 4). The first two components, PC1 (33.50\%) and PC2 (17.45\%), exhibited the greatest contribution and represented $50.95 \%$ of the total variance in the dataset. The replications of the same treatments (media) were clustered nearby, while the different treatments were clearly divided by the first two components (Figure 4A). This division of the treatments clearly indicated that the PP, PPB, and PPBC treatments had a considerable ameliorative influence on the evaluated parameters of potted A. zerumbet plants. Moreover, the first group of variables PCA, such as PC1, is positively correlated with several parameters like shoot dry weight, number of side shoots per plant, leaf area, number of leaves, root dry mass, visual quality, leaf $\mathrm{N}$, leaf $\mathrm{P}$, leaf $\mathrm{K}$, photosynthesis rate $\mathrm{Pn}$, E, chlorophyll a, chlorophyll b, total chlorophyll, and SPAD (Figure 4B). On the other hand, a significant negative 
correlation of PC1 variables including shoot diameter, container capacity, Gs, bulk density, total porosity, $\mathrm{pH}$, air space, and leaf thickness was found with the variables associated with PC2 (Figure 4B).

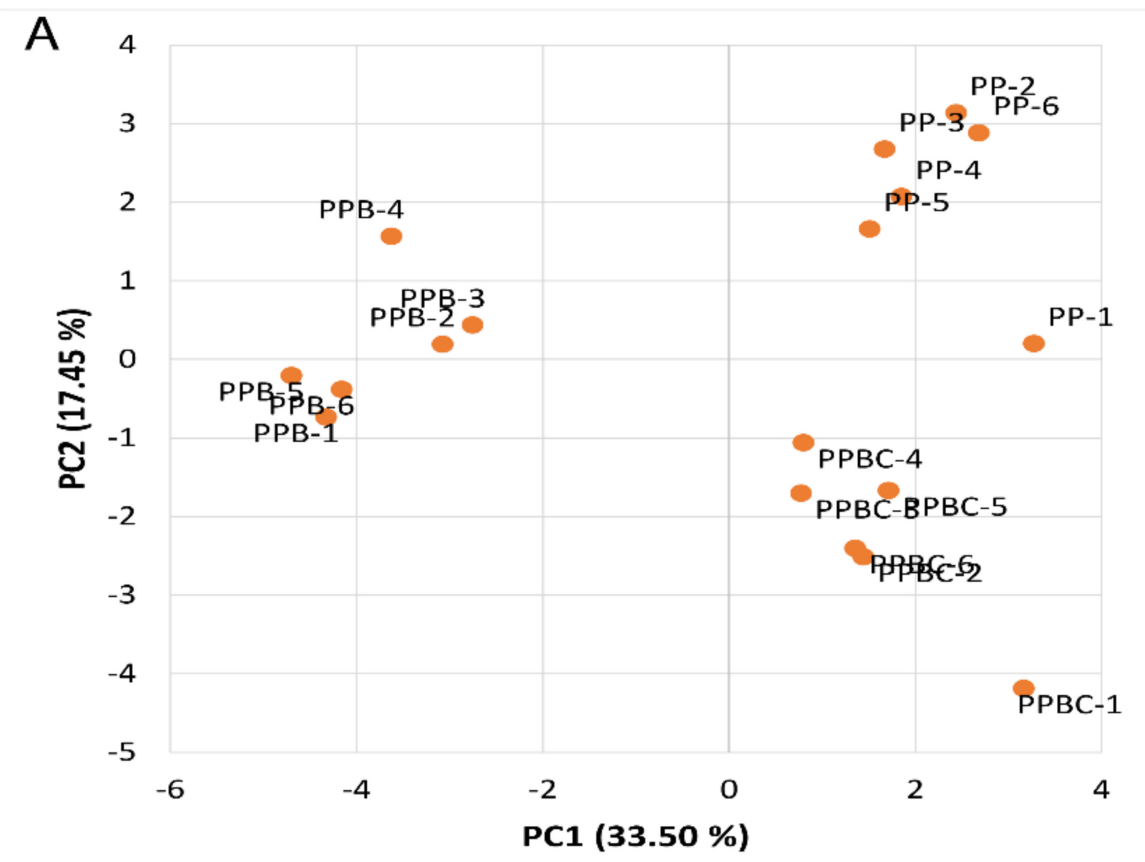

\section{B}

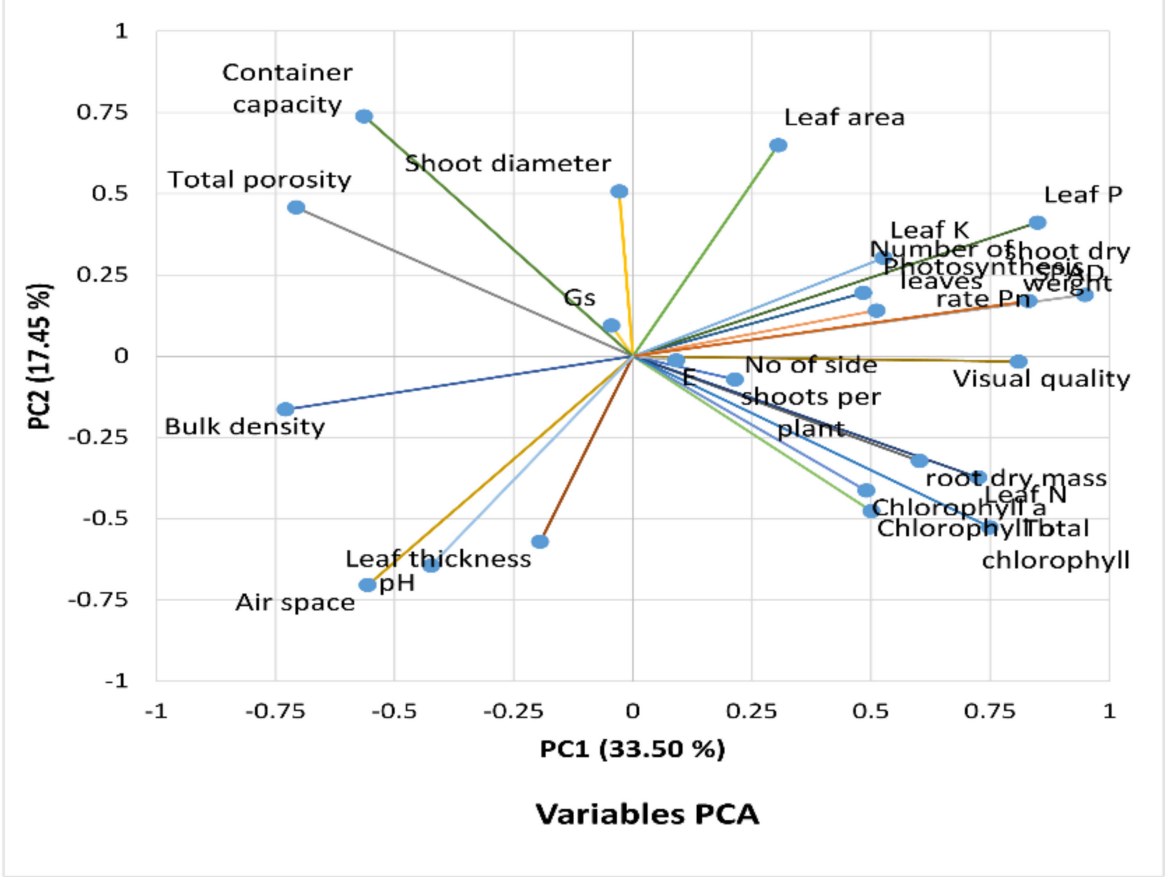

Figure 4. Principal component analysis (PCA) of (A) individual treatments PCA and (B) different parameters/variables PCA of potted A. zerumbet grown in peat:perlite (PP), peat:perlite:biochar (PPB), and peat:perlite:biochar:compost (PPBC) media, respectively. (A) The score plot indicates the distribution of treatments (media). The numbers (1-6) with PP, PPB, and PPBC represent the number of replications. 


\section{Conclusions}

Our study showed that marketable Alpinia plants were produced in modified potting media supplemented with $30 \%$ of rice biochar (PPB) or $35 \%$ of the biochar with $5 \%$ of compost (PPBC). The TP, AS, and BD of the PPN and PPBC were within or very close to the ideal ranges for the physical properties required to grow plants in containers. However, PPB suppressed the growth of Alpinia, as reflected by significantly lower dry matter accumulation and a lower visual quality rating. The addition of vermicompost at $5 \%$ alleviated the suppression. The reduced growth may be due to high $\mathrm{pH} / \mathrm{EC}$, or to increased binding of $\mathrm{N}$ by a high rate of biochar. On the other hand, $5 \%$ vermicompost addition might act as a buffer to mediate the physiochemical and biological activities of the potting medium and provide additional nutrients for improved plant growth. Since ornamental plants are valued for their aesthetic appearance, it is recommended that $A$. zerumbet plants should be produced in a potting medium comprised of peat:perlite:biochar:vermicompost at 30:30:35:5 by volume. Such a practice can produce high quality plants and benefit growers in the foliage plant industry. Furthermore, this practice can substantially reduce peat use in the formulation of potting medium, thus contributing to the conservation of peatlands.

Author Contributions: Conceptualization, F.Z. and A.Y.; methodology, F.Z. and A.Y.; formal analysis, F.Z.; data curation, F.Z. and N.S.; writing - original draft preparation, F.Z.; writing-review and editing, F.Z., X.W., J.C., A.R., A.Y., M.N. (Muhammad Nafees), Z.A., A.Z., N.L., M.N. (Muhammad Naveed) and K.H.M.S.; supervision, A.Y. and J.C.; All authors have read and agreed to the published version of the manuscript.

Funding: This research received no external funding.

Institutional Review Board Statement: Not applicable.

Informed Consent Statement: Not applicable.

Data Availability Statement: Data presented in this study are available in the article.

Conflicts of Interest: The authors declare no conflict of interest.

\section{References}

1. Chen, J.; McConnell, D.B.; Henny, R.J.; Norman, D.J. The foliage plant industry. Hortic. Rev. 2004, 31, 45-110. [CrossRef]

2. Arora, S.; Jung, J.; Liu, M.; Li, X.; Goel, A.; Chen, J.; Song, S.; Anderson, C.; Chen, D.; Leong, K.; et al. Gasification biochar from horticultural waste: An exemplar of the circular economy in Singapore. Sci. Total Environ. 2021, 781, 146573. [CrossRef]

3. Vandecasteele, B.; Blindeman, L.; Amery, F.; Pieters, C.; Ommeslag, S.; Van Loo, K.; De Tender, C.; Debode, J. Grow—StoreSteam—Re-peat: Reuse of spent growing media for circular cultivation of Chrysanthemum. J. Clean. Prod. 2020, 276, 124128. [CrossRef]

4. Chen, J.; Wei, X. Controlled-released fertilizers as a means to reduce nitrogen leaching and runoff in container-grown plant production. In Nitrogen in Agriculture — Updates; Khan, A., Fahad, S., Eds.; IntechOpen: London, UK, 2018; pp. 33-52.

5. Zawadzińska, A.; Salachna, P.; Nowak, J.; Kowalczyk, W. Response of interspecific geraniums to waste wood fiber substrates and additional fertilization. Agriculture 2021, 11, 119. [CrossRef]

6. Li, X.; Xia, H.; Wang, J.; Chen, Q. Nutrient uptake and assimilation in fragrant rosewood (Dalbergia odorifera T.C. Chen) seedlings in growing media with un-composted spent mushroom residue. PLoS ONE 2021, 16, e249534. [CrossRef]

7. Zulfiqar, F.; Allaire, S.E.; Akram, N.A.; Méndez, A.; Younis, A.; Peerzada, A.M.; Shaukat, N.; Wright, S.R. Challenges in organic component selection and biochar as an opportunity in potting substrates: A review. J. Plant Nutr. 2019, 42, 1386-1401. [CrossRef]

8. Zulfiqar, F.; Younis, A.; Asif, M.; Abideen, Z.; Allaire, S.E.; Shao, Q. Evaluation of container substrates containing compost and biochar for ornamental plant Dracaena deremensis. Pak. J. Agric. Sci. 2019, 56, 613-621.

9. Zulfiqar, F.; Younis, A.; Chen, J. Biochar or biochar-compost amendment to a peat-based substrate improves growth of Syngonium podophyllum. Agronomy 2019, 9, 460. [CrossRef]

10. Nobile, C.; Denier, J.; Houben, D. Linking biochar properties to biomass of basil, lettuce and pansy cultivated in growing media. Sci. Hortic. 2020, 261, 109001. [CrossRef]

11. Huang, L.; Gu, M.; Yu, P.; Zhou, C.; Liu, X. Biochar and vermicompost amendments affect substrate properties and plant growth of basil and tomato. Agronomy 2020, 10, 224. [CrossRef]

12. Amery, F.; Debode, J.; Ommeslag, S.; Visser, R.; De Tender, C.; Vandecasteele, B. Biochar for circular horticulture: Feedstock related effects in soilless cultivation. Agronomy 2021, 11, 629. [CrossRef] 
13. Gvero, P.M.; Papuga, S.; Mujanic, I.; Vaskovic, S. Pyrolysis as a key process in biomass combustion and thermochemical conversion. Therm. Sci. 2016, 20, 1209-1222. [CrossRef]

14. Yan, J.; Yu, P.; Liu, C.; Li, Q.; Gu, M. Replacing peat moss with mixed hardwood biochar as container substrates to produce five types of mint (Mentha spp.). Ind. Crop. Prod. 2020, 155, 112820. [CrossRef]

15. Yu, P.; Huang, L.; Li, Q.; Lima, I.M.; White, P.M.; Gu, M. Effects of mixed hardwood and sugarcane biochar as bark-based substrate substitutes on container plants production and nutrient leaching. Agronomy 2020, 10, 156. [CrossRef]

16. Vaughn, S.F.; Eller, F.J; Evangelista, R.L.; Moser, B.R.; Lee, E.; Wagner, R.E.; Peterson, S.C. Evaluation of biochar-anaerobic potato digestate mixtures as renewable components of horticultural potting media. Ind. Crop. Prod. 2015, 65, 467-471. [CrossRef]

17. Huang, L.; Gu, M. Effects of biochar on container substrate properties and growth of plants-A review. Horticulturae 2019, 5, 14. [CrossRef]

18. Fascella, G.; Mammano, M.M.; D'Angiolillo, F.; Rouphael, Y. Effects of conifer wood biochar as a substrate component on ornamental performance, photosynthetic activity, and mineral composition of potted Rosa rugosa. J. Hortic. Sci. Biotechnol. 2017, 93, 519-528. [CrossRef]

19. Gu, M.; Li, Q.; Steele, P.H.; Niu, G.; Yu, F. Growth of 'fireworks' gomphrena grown in substrates amended with biochar. J. Food Agric. Environ. 2013, 11, 819-821.

20. Dispenza, V.; De Pasquale, C.; Fascella, G.; Mammano, M.M.; Alonzo, G. Use of biochar as peat substitute for growing substrates of Euphorbia $\times$ lomi potted plants. Span. J. Agric. Res. 2016, 14, e0908. [CrossRef]

21. Guo, Y.; Niu, G.; Starman, T.; Gu, M. Growth and development of Easter lily in response to container substrate with biochar. J. Hortic. Sci. Biotechnol. 2018, 94, 80-86. [CrossRef]

22. Alvarez, J.; Pasian, C.; Lal, R.; Lapez, R.; Fernandez, M. Vermicompost and biochar as substitutes of growing media in ornamentalplant production. J. Appl. Hortic. 2017, 19, 205-214. [CrossRef]

23. Huang, L.; Niu, G.; Feagley, S.E.; Gu, M. Evaluation of a hardwood biochar and two composts mixes as replacements for a peat-based commercial substrate. Ind. Crop. Prod. 2019, 129, 549-560. [CrossRef]

24. Bustamante, M.; Gomis, M.; Pérez-Murcia, M.; Gangi, D.; Ceglie, F.; Paredes, C.; Pérez-Espinosa, A.; Bernal, M.; Moral, R. Use of livestock waste composts as nursery growing media: Effect of a washing pre-treatment. Sci. Hortic. 2021, 281, 109954. [CrossRef]

25. Liu, R.; Gu, M.; Huang, L.; Yu, F.; Jung, S.-K.; Choi, H.-S. Effect of pine wood biochar mixed with two types of compost on growth of bell pepper (Capsicum annuum L.). Hortic. Environ. Biotechnol. 2019, 60, 313-319. [CrossRef]

26. Yu, H.; Zou, W.; Chen, J.; Chen, H.; Yu, Z.; Huang, J.; Tang, H.; Wei, X.; Gao, B. Biochar amendment improves crop production in problem soils: A review. J. Environ. Manag. 2019, 232, 8-21. [CrossRef]

27. Chen, J.; Stamps, R.H. Cutting propagation of foliage plants. In Cutting Propagatio: A Guide to Propagating and Producing Floriculture Crops; Dole, J.M., Gibson, J.L., Eds.; Ball Publishing: Batavia, IL, USA, 2006; pp. 203-228.

28. Tian, Y.; Sun, X.; Li, S.; Wang, H.; Wang, L.; Cao, J.; Zhang, L. Biochar made from green waste as peat substitute in growth media for Calathea rotundifola cv. Fasciata. Sci. Hortic. 2012, 143, 15-18. [CrossRef]

29. Méndez, A.; Paz-Ferreiro, J.; Gil, E.; Gascó, G. The effect of paper sludge and biochar addition on brown peat and coir based growing media properties. Sci. Hortic. 2015, 193, 225-230. [CrossRef]

30. Nieto, A.; Gascó, G.; Paz-Ferreiro, J.; Fernández, J.; Plaza, C.; Méndez, A. The effect of pruning waste and biochar addition on brown peat based growing media properties. Sci. Hortic. 2016, 199, 142-148. [CrossRef]

31. Rhoades, J.D. Salinity: Electrical conductivity and total dissolved solids. In Methods of Soil Analysis, Part 3, Chemical Methods; Sparks, D.L., Page, A.L., Helmke, P.A., Loeppert, R.H., Soltanpour, P.N., Tabatabai, M.A., Johnston, C.T., Sumner, M.E., Eds.; Soil Science Society of America: Madison, WI, USA, 1996; Volume 5, pp. 417-435.

32. Thomas, G.W. Soil pH and Soil Acidity. Micronutr. Agric. 2018, 3, 475-490. [CrossRef]

33. Arnon, D.I. Copper enzyme in isolated chloroplast: Polyphenol oxidase in Beta vulgaris. Plant Physiol. 1949, 24, 1-15. [CrossRef] [PubMed]

34. Jackson, M.L. Soil Chemical Analysis; Constable and Co. Ltd.: London, UK, 1962.

35. Chapman, H.D.; Pratt, P.F. Methods of Analysis for Soils, Plants and Water; University of California, Division of Agriculture Science Riverside: Riverside, CA, USA, 1961.

36. Bilderback, T.E.; Warren, S.L.; Owen, J.S., Jr.; Albano, J.P. Healthy substrates need physicals too! Hort. Technol. 2005, 15, 747-751. [CrossRef]

37. Chen, J.; McConnell, D.B.; Robinson, C.A.; Caldwell, R.D.; Huang, Y. Production and interior performances of tropical ornamental foliage plants grown in container substrates amended with composts. Compos. Sci. Util. 2002, 10, 217-225. [CrossRef]

38. Abad, M.; Fornes, F.; Carrión, C.; Noguera, V.; Noguera, P.; Maquieira, A.; Puchades, R. Physical properties of various coconut coir dusts compared to peat. HortScience 2005, 40, 2138-2144. [CrossRef]

39. Dumroese, R.K.; Heiskanen, J.; Englund, K.; Tervahauta, A. Pelleted biochar: Chemical and physical properties show potential use as a substrate in container nurseries. Biomass Bioenergy 2011, 35, 2018-2027. [CrossRef]

40. Fonteno, W.; Hardin, C.; Brewster, J. Procedures for Determining Physical Properties of Horticultural Substrates Using the NCSU Porometer. Horticultural Substrates Laboratory, North Carolina State University. 1995. Available online: https://projects.ncsu. edu/project/hortsublab/pdf/porometer_manual.pdf (accessed on 3 October 2021).

41. Gruda, N.; Schnitzler, W. Suitability of wood fiber substrate for production of vegetable transplants. Sci. Hortic. 2004, 100, 309-322. [CrossRef] 
42. Xing, J.; Gruda, N.; Xiong, J.; Liu, W. Influence of organic substrates on nutrient accumulation and proteome changes in tomato-roots. Sci. Hortic. 2019, 252, 192-200. [CrossRef]

43. Hicklenton, P.R.; Rodd, V.; Warman, P.R. The effectiveness and consistency of source-separated municipal solid waste and bark composts as components of container growing media. Sci. Hortic. 2001, 91, 365-378. [CrossRef]

44. Zhang, L.; Sun, X.-Y.; Tian, Y.; Gong, X.-Q. Biochar and humic acid amendments improve the quality of composted green waste as a growth medium for the ornamental plant Calathea insignis. Sci. Hortic. 2014, 176, 70-78. [CrossRef]

45. Méndez, A.; Cárdenas-Aguiar, E.; Paz-Ferreiro, J.; Plaza, C.; Gascó, G. The effect of sewage sludge biochar on peat-based growing media. Biol. Agric. Hortic. 2017, 33, 40-51. [CrossRef]

46. Maroušek, J.; Vochozka, M.; Plachý, J.; Žák, J. Glory and misery of biochar. Clean Technol. Environ. Policy 2017, 19, 311-317. [CrossRef]

47. Margenot, A.J.; Griffin, D.; Alves, B.S.; Rippner, D.A.; Li, C.; Parikh, S.J. Substitution of peat moss with softwood biochar for soil-free marigold growth. Ind. Crop. Prod. 2018, 112, 160-169. [CrossRef]

48. Altland, J.E.; Locke, J.C. Biochar affects macronutrient leaching from a soilless substrate. HortScience 2012, 47, 1136-1140. [CrossRef]

49. Fidel, R.B.; Laird, D.A.; Spokas, K.A. Sorption of ammonium and nitrate to biochars is electrostatic and pH-dependent. Sci. Rep. 2018, 8, 17627. [CrossRef]

50. Bryson, G.M.; Mills, H.A.; Sasseville, D.N.; Jones, J.B.; Barker, A.V. Plant Analysis Handbook III: A Guide to Sampling, Preparation, Analysis, Interpretation and Use of Results of Agronomic and Horticultural Crop Plant Tissue; Micro-Macro Publishing: Athens, GA, USA, 2014.

51. Kim, H.S.; Kim, K.R.; Yang, J.-E.; Ok, Y.S.; Kim, W.I.; Kunhikrishnan, A.; Kim, K.-H. Amelioration of horticultural growing media properties through rice hull biochar incorporation. Waste Biomass Valoriz. 2017, 8, 483-492. [CrossRef]

52. Guo, Y.; Niu, G.; Starman, T.; Volder, A.; Gu, M. Poinsettia growth and development response to container root substrate with biochar. Horticulturae 2018, 4, 1. [CrossRef]

53. Leiber-Sauheitl, K.; Bohne, H.; Böttcher, J. First steps toward a test procedure to identify peat substitutes for growing media by means of chemical, physical, and biological material characteristics. Horticulturae 2021, 7, 164. [CrossRef]

54. Housley, C.; Kachenko, A.G.; Singh, B. Effects of Eucalyptus saligna biochar-amended media on the growth of Acmena smithii, Viola var. hybrida, and Viola $\times$ wittrockiana. J. Hortic. Sci. Biotechnol. 2015, 90, 187-194. [CrossRef]

55. Wang, Q.; Chen, J.; Stamps, R.H.; Li, Y. Correlation of visual quality grading and SPAD reading of green-leaved foliage plants. J. Plant Nutr. 2005, 28, 1215-1225. [CrossRef] 